\title{
Bridging the Centuries: A Brief Biography of Wamanrao Varde Valaulikar
}

Transpondo os séculos: uma breve biografia de Wamanrao Varde Valaulikar

En transposant les siècles: une brève biographie de Wamanrao Varde Valaulikar

Jason Keith Fernandes

\section{OpenEdition}

\section{Journals}

Electronic version

URL: http://journals.openedition.org/rccs/7048

DOI: $10.4000 /$ rccs.7048

ISSN: 2182-7435

Publisher

Centro de Estudos Sociais da Universidade de Coimbra

Printed version

Date of publication: 1 May 2018

Number of pages: 183-204

ISSN: 0254-1106

\section{Electronic reference}

Jason Keith Fernandes, «Bridging the Centuries: A Brief Biography of Wamanrao Varde Valaulikar» Revista Crítica de Ciências Sociais [Online], 115 | 2018, Online since 15 May 2018, connection on 19 April 2019. URL : http://journals.openedition.org/rccs/7048 ; DOI : 10.4000/rccs.7048 


\title{
JASON KEITH FERNANDES
}

\section{Bridging the Centuries: A Brief Biography of Wamanrao Varde Valaulikar*}

\begin{abstract}
The extant representations of the late nineteenth-century personality Wamanrao Varde Valaulikar (1877-1946), known as Shenoi Goembab to Konkani activists, are marked by a hagiographical character. The present article offers a biography of the man which eschews these nationalist hagiographies to place the man in the context of his times and to demonstrate his primary role as an activist in the creation of the Gaud Saraswat Brahmin caste. In so doing, the article demonstrates how the foundations for the contemporary Goan public sphere were laid in the nineteenth century.
\end{abstract}

Keywords: activism; Goa; Konkani language; Shenoi Goembab; Wamanrao Varde Valaulikar (1877-1946).

\section{Introduction}

In 2002 the state of Goa sought to commemorate the $125^{\text {th }}$ birth anniversary of Wamanrao Varde Valaulikar (Valaulikar) as Konkani Asmitai Divas (Konkani Pride Day). Born into a Hindu brahmin family in 1877 in Bicholim, Valaulikar has been acclaimed by his pen-name Shenoi Goembab, and elevated by the state-favoured Konkani language establishment as the 'Father' of the Konkani Language movement. This status is signal in a territory whose dominant identity has been constructed in close association with the Konkani language, and where Konkani, or at least one particular form of Konkani, has been recognised as the official language of the state. However, despite this critical position that Valaulikar holds in the Goan public sphere, there is practically no scholarly biography of the man. Rather, what obtains are a number of cloying, sentimental narratives verging on hagiographies (Budkuley, 2003; Naik, 2007). To redress this gap this essay

* The research for this work was supported by the Fundação para a Ciência e a Tecnologia (Portugal) under grant SFRH/BD/47423/2008. This work has been written with support from the Fundação para a Ciência e a Tecnologia (Portugal) under grant SFRH/BPD/98046/2013. 
will offer a contextualised reading of Valaulikar's biography and project. ${ }^{1}$ In doing so, this article will point to the problems with narratives consonant with Indian secularism, which occlude the operation of caste ${ }^{2}$ and thus hide the manner in which contemporary Indian civil society is based on the interests of dominant brahmanical Hindu castes.

Evaluating Valaulikar's project, it may well be said that the man is indeed deserving of the credit that the Goan state grants him. The scheme that Valaulikar identified has been crucial to the forging of the Konkani language project. This project is one that identified Konkani as the language of Goa and Devanagari (Nagari) as the ideal script for the language, Antruzi ${ }^{3}$ as the finest form of the language, and hence one that deserves to be the basis for the standard literary form as well as the state sponsored form. This attention to language in Goa should be understood in the context of the linguistic politics in the sub-continent. Starting with the creation in 1956 of the state of Andhra Pradesh as a Telugu-speaking administrative territory from the former multilingual state of Madras, the "linguistic principle" was framed as a cultural bond and administrative facilitator for socio-economic prosperity leading to the creation of linguistic states (Keiko, 2010). The state of Maharashtra was formed in 1960 from the former multilingual state of Bombay in the face of demands from organisations such as the Samyukta Maharashtra Parishad (Committee for a United Maharashtra) to unite all areas with Marathi-speaking populations (or dominated by such linguistic populations at any rate). Following India's annexation of Goa in 1961, the demands of these pro-Marathi organisations included that Goa too be integrated into Maharashtra. In this context, despite the linguistic diversity within the territory and the complex relationships that Goans had with various languages, Konkani was identified as the language of all Goans by those groups in Goa opposed to this proposed integration. Commencing with the Opinion Poll, the referendum in 1967 on whether residents of Goa

\footnotetext{
${ }^{1}$ I use "project" as a term that draws attention "not towards a totality such as a culture, nor to a period that can be defined independently of people's perceptions and strategies, but rather to a socially transformative endeavour that is localized, politicized, and partial, yet also engendered by longer historical developments and ways of narrating them" (Thomas apud Ramaswamy, 1997: 22-23). ${ }^{2}$ For a quick overview of the operation of secularism in India see Brass (2005), and Dhareshwar (1993). Dhareshwar's text is particularly useful to understand the manner in which British Indian nationalists from dominant castes suppressed the caste question when addressing the question of anti-colonial resistance. This ensure that the mention of caste-based injustice in public discourse attracted accusations and charges of being anti-secular, which as Brass demonstrates, effectively represented a challenge to the consensus established by dominant castes.

3 Even though the spoken language form privileged by the state government is recognized as Antruzi, a variety of activists from non-brahmin castes point out that the dialect is more appropriately termed Bamani, or the speech of brahmins (from the Antruz region).
} 
preferred the territory to be merged with Maharashtra or not, and until the resolution of the question in 1987 when the legislative assembly of Goa passed the Official Language Act in which the state recognised Konkani in the Nagari script as the official language of the territory, language and its form came to be an all-important lens through which Goan identity was defined (Fernandes, 2013).

This legislative fixing of officially recognised Konkani was not unproblematic. This recognition was seen as licence to impose the version mooted by Valaulikar instead of the Roman-scripted Konkani popular in Goa, especially among the Catholic masses. This privileging of one form and the simultaneous disapproval of another has ensured the identification of the brahmin (or brahmanical) as the ideal post-colonial Indo-Goan instead of the colonial period Luso-Goan. Like others of its kind, however, Valaulikar's project which eventually came to fruition in 1987, would not have been engendered without longer historical developments and the associated narratives. Valaulikar, a man who spanned the century under our collective consideration and the subsequent twentieth century, was a bridge between trajectories that first commenced in nineteenth-century Goa by the actors Joaquim Heliodoro da Cunha Rivara (Rivara), a metropolitan Portuguese civil servant heading the administrative establishment in Goa, and the native Catholic elite. ${ }^{4}$ Valaulikar simply cannot be examined without due reference to the political history of the language that was first forged by the Catholic and Portuguese-speaking native elite of the Estado in the nineteenth century.

\section{Bridging the Centuries}

In her text Between Empires (2007), which studies the Goan Catholic elite and their relationship with print politics in the nineteenth century, Rochelle Pinto suggests that their "prolific output [...] stapled the nineteenth century into historical and cultural frameworks that would outlast their moment of origin, to become resilient filters through which the century and its aftermath would be received" (ibidem: 1). Problematising the hitherto dominant historiography of Goa, Pinto points out that "[A] privileging of the periodization (sixteenth to seventeenth centuries) that was economically significant for the Portuguese colonial empire, or of that leading to the Liberation [sic] of Goa and after (mid-twentieth), has led to a comparative absence of work on the nineteenth

\footnotetext{
${ }^{4}$ I find the term 'native' elite, which refers to the Catholic brahmin and chardo castes, quite troubling because it effectively denies the fact that the descendentes, a mixed race group, were also native to and based in Goa, many of whom continue to see Goa as home, given that prior to leaving Goa in the wake of its annexation they had spent generations in that territory. I nevertheless use this terminology for lack of an alternative.
} 
century" (ibidem: 2). As such, I frame the life and work of Valaulikar, who was born and died within this period, the description of whose politics has largely been absent. Concurring with Pinto, I argue that this was not a stagnant period, as has been suggested by some, but the moment when the linguistic politics in post-colonial Goa, described above, were being put into place. What I would like to particularly emphasise through this essay, and its focus on Valaulikar, is that the basis of contemporary Goan citizenship practices was forged through context crafted in the nineteenth century.

In his reminisces, Valaulikar is reported to have credited the Second Baron of Cumbarjua, Tomás Mourão (1842-1904), with inspiring him onto the task of reviving Konkani as a language that would unite all Goans (Valavalikar, 2003: 25). He recounts that having written a Marathi-Portuguese primer, $O$ mestre português, he submitted it for approval to the Baron, who was Inspector of Schools in Goa at the time. The Baron was one of those enthusiasts who attempted to introduce Konkani into the school system of Goa. The Konkani language seems to have first attracted the attention of the modern Portuguese state through the efforts of Rivara (1809-1879) who functioned as the secretary-general to the Governor General (1856 to 1870) and held other official posts in the territory. As Commissioner of Instruction concerned with the dismal efforts directed at educating the population of the territory, he suggested that a new language could only be learnt by the comparison of its mechanics with that of one's mother tongue, and as such, the "concanim language should be made a starting point to teach the Indians any other language" (Botelho, 2011: 103).

Something similar was unfolding in the neighbouring British Indian province of the Bombay Presidency. There, with the establishment of the University of Bombay in 1857, English was instituted as the sole language of higher learning, resulting in the fixing of the vernacular as suitable only for lower education. Veena Naregal points out that this had an important impact on the politics of the local elites in the Presidency who had until then, not unlike the Hindu elites in Goa, followed a politics of dissemination of education and egalitarian ideals in the Marathi language. From 1857 onwards, their politics shifted to that of 'representation' where they gained higher education in English, restricted the education of the masses to Marathi, and presented their versions of the vernacular as representative of the ideal forms of the language, a process that, as I shall demonstrate below, was not dissimilar to what would happen through Valaulikar's exertions for Konkani (Naregal, 2001: 118, 137, 147-148).

The efforts to recognise the Konkani language as the local vernacular and introduce it into public education were, however, stiffly resisted through 
the efforts of such members of the Hindu elite as Suriaji Anand Rao (18281888), the Marathi interpreter to the government. ${ }^{5}$ This drama seems to have played out between 1859, when António Vasconcelos Correia, the Governor-General (between1855-1864), whom Rivara accompanied to India, accepted the latter's recommendations that Konkani be used in primary education, and 1869 when Governor Pestana (governing between 1844-1851 and 1864-1870) banned Konkani in schools.

Pinto suggests that the support in favour of Marathi and against Konkani may have come from these elite Hindus primarily because it stood to "overturn what had already been achieved [in getting official state recognition for Marathi] through their own efforts and through the official support of the Catholic elite" (2007: 105). ${ }^{6}$

The Baron himself had written a primer in Konkani in 1888-1889. This effort was probably after the debacle in 1871 when subsequent to an order to convert the Portuguese language schools in the Novas Conquistas into bilingual schools, that is Portuguese-Marathi and Portuguese-Konkani, it was discovered that no Konkani books existed and hence the language could not be introduced into the educational system at the time (Botelho, 2011: 103-104). It was in this context that the Baron corrected Valaulikar's assertion that the lingua vernacular (local language) of the Goans was not Marathi, as stated in the latter's $O$ mestre português, but Konkani (Valavalikar, 2003: 25).

Valaulikar's hagiographies dramatise this correction as the moment when Valaulikar is said to have recognised his error and subsequently worked to develop Konkani. Valaulikar's project must consequently be seen as a continuation of, or at the very least, inspired by the intellectual concerns of segments of the Goan Catholic elite. Sandra Lobo, draws attention to the fact that the Baron was a descendente, a social group in competition with the native Catholic elite at the time. She suggests that Rivara and the Baron's project was frustrated precisely because of the lack of support from the native elite. It should be noted, however, that given his social status as Hindu, and his physical location in the British Indian city of Bombay for most of his life, his works were simultaneously also influenced by the

\footnotetext{
${ }^{5}$ Contrary to popular opinion, the Hindu elites, and especially the brahmin groups were crucial to the continuing presence of the Portuguese state in India almost since its very inception (Pearson, 1972) until the end of the Estado.

${ }^{6}$ Indeed, it appears that these Hindu elites sought to incorporate themselves into the Portuguese polity through Marathi. In his text Konkani Bhashechem Zoit, Valaulikar writes that "they [i.e. the Hindu elites] are exerting themselves to earn the facility of ballot papers in Marathi during the elections" (Valavalikar, 2003: 24). He was probably referring to the efforts made by upper-caste Hindu leaders in the 1920s (reported in the Marathi language newspaper in 22 March 1924).
} 
trajectories of anti-colonial nationalism unfolding in British India. Indeed, it appears as if the secular compact that saw Hindu and Catholic elites stand together for Konkani subsequent to the annexation of Goa was the result of Valaulikar's efforts.

The smoothness and ease with which the hagiographies represent Valaulikar as having recognised his mistake regarding the local tongue of Goans erases the internal conflicts that seem to have wracked Goan Hindu brahmin society in those tumultuous years at the cusp of the twentieth century. This conflict is also expunged because of the manner in which the operations of caste are erased by those consciously writing in the "secular" sphere (Dhareshwar, 1993). A visibilising of caste makes not only the context within which Valaulikar operated much more obvious but also the manoeuvres he effected that propelled his caste into the space of civil society.

\section{The Creation of the Gaud Saraswat Caste}

A fact that is often not elaborated upon or drawn into analysis is that Valaulikar was a member of what is today recognised as the Gaud Saraswat Brahmin (GSB) caste. This occlusion is because of the nature of secular nationalist narratives that seek to efface the operation of caste. While this caste is dominant in Goa today, generally recognised as brahmin and seen as a single block, this was not always the case. On the contrary, the late nineteenth and early twentieth century was a period when this caste was first consolidated through a unification process of "several related jatis" (Conlon, 1974: 352).

The process that led to the unification of these various jati into the GSB seems to have been motivated by a number of factors. The first was the fact that in the nineteenth century the sub-continent saw the rise of a number of caste associations that sought to group related jati together and standardise customs and identities in their bid to make claims on the state. A singular fact that aided this process was, without a doubt, the British collection of numerical data on caste in India. The British administration of the census in the latter half of the nineteenth century set in motion various discursive practices that resulted in caste identities becoming standardised, their numbers simplified, the boundaries between them solidified, and the hierarchical relationships amongst them codified (Narayan, 2004: 198-199). Leaders within the related jati that would form the GSB similarly felt the need to consolidate a group as a number of migrants to Bombay from these jati fought for securing employment options within the British Raj's Bombay Presidency. The idea was to forge a unity between groups that had some kind of linkages, to create support for the recent migrants to the city with the older established families already resident in the city of Bombay. "It was hoped that this would 
confer benefits to those already in the competitive urban arena and enable disadvantaged GSB families to gain access to education and employment" (Conlon, 1974: 352). It was not an uncommon practice for newly literate groups from humble backgrounds to seek entry into the colonial revenue service and claim affinities of blood and caste with those families that had established themselves in earlier times (Bayly, 2001: 71). Valaulikar would have fit the profile of this group admirably. Valaulikar's biographies indicate that his father was a "poor" shopkeeper in Bicholim as well as a manager of the household of a wealthy relative (Naik, 2007: 1). Nonetheless, the family could also lay claim to an illustrious past where the progenitor of his line was a diplomat for a local potentate at viceregal court, and another was "Delegate or Ambassador of the Portuguese Government at the Court of the Peshwas in Pune" and powerful enough, according to this narrative, to stem the proselytising zeal of the Portuguese at the time of the annexation of Ponda into the Estado da Índia (ibidem).

These claims to affinity with the powerful families established in Bombay do not seem to have gone down very well with the latter, who resented the assertions of the new entrants. One of the areas of contestation was the right of these new entrants in terms of co-management of the temples controlled by the established families (Conlon, 1974: 355). Parag Parabo points out that

Shenvis from Bombay who had now been present in the city for almost two centuries regarded themselves as true GSBs from Bombay and aimed to reserve the maintenance of several temples as their hereditary right. This was contested in court in 1898 where Justice Tyabji ordered that any GSB subcaste would be eligible for the membership. (2015:30)

The call for unity was thus first articulated against the Shenvi jati who were being represented as GSB against their will.

The need for unity itself stemmed from "the spill over of the debate in the nineteenth century that questioned the brahmin status of Gaud Saraswat brahmins" but in fact was premised on debates that reached further back into the early modern period (Desai, 2002: 112; see also Patil, 2010; O'Hanlon and Minkowski, 2008; and Conlon, 1977:39). In the nineteenth century, this challenge to these multiple caste groups came from the Marathi-speaking Chitpawan brahmins who were a dominant group in the Bombay Presidency. This challenge to their brahmin status had not merely social repercussions but also wider and especially economic implications as well, given that it could jeopardise their access to public office. Take, for example, the case of Sir Ramakrishna Gopal Bhandarkar. A man whose career was otherwise 
celebrated as a gain for senior appointments in government establishments (Naregal, 2001: 48), Bhandarkar was not allowed by the Pune brahmins to take part as a principal participant in a Shastrartha Sabha on the age of marriage. These brahmins reasoned that because he was a GSB, and not brahmin, he was not entitled to participate in a brahmin-only assembly. Ensuring that they were recognised as brahmin was critical to these jati for a number of reasons. In discussing the Malvankar and Wagle debate - another case which challenged the brahmin status of the Saraswats - Urmila Patil provides a critical answer. First, accessing brahmin status and the rights to have Saraswats as priests would allow these $j a t i$ to bind together and create a stronger corporate identity, critical given that jobs were obtained through kin-networks, and in this way a check on the growing influence of the Chitpawan brahmins in the city of Bombay (Patil, 2010: 237). Secondly, those who stood at the helm of scholarly production also controlled the boundaries of permissible norms and practices in accordance with their own interests. As pointed out earlier, this was a period when the state government was sponsoring dictionaries and encyclopaedias in order to standardise the vernacular languages to ensure better administration and communication with the indigenous population. The logic of the time held that the speech of brahmins was considered purer than those of others, ${ }^{7}$ and that in the Marathi world it was the Chitpawans who were singled out as the exemplary brahmin community. It became vital, therefore, that the GSB be considered brahmin not only in the interest of placing themselves in this powerful position but also to ensure that Chitpawan norms did not define them out of power (ibidem: 253-254). Finally and perhaps most importantly was the fact that the Dharmasastras were used by both liberals and conservatives as the basis for social reform or its opposition. At the end of the day, it was brahmin status that allowed for one to be seen as an authentic interpreter of the sastras (ibidem: 275). All of these factors combined to provide an added impetus to coalesce and establish their combined brahmin identity (Conlon, 1974).

This peculiar situation that these migrants faced forced them to identify as constituent features of their caste those markers which would simultaneously assert for them a brahmin identity. The unification movement consequently determined that the GSB was marked out by features of clan (gotra),

\footnotetext{
${ }^{7}$ Pinto provides information that indicates that Rivara himself saw brahmin speech as exemplary of the highest standard of vernacular speech. She reports that he saw the "intermingling of many Portuguese words particularly in the speech of the Catholic Goans' as a sign of 'corruption of the language and its enslavement" (2007: 104). And also that "He berated the chardo community for their claim that the brahmanical elements in the speech of Catholic and Hindu brahmins were signs of affectation and corruption" (ibidem). In other words, brahmanical elements were not corruption, but in fact the mark of authenticity.
} 
family deity (kuladeva), village, family and allegiance to a lineage of spiritual descent (guru parampara) of preceptors (swamis) (Bayly, 2001: 75). Given the resistance these jati faced from the Marathi-speaking brahmins that dominated Bombay, it is perhaps little wonder that in a set of double moves, ones which combined nineteenth-century western European epistemologies with the needs peculiar to a caste battle, these caste unifiers identified their "mother-tongue" Konkani as another marker of the GSB caste.

A scientific effort that significantly aided this process was the introduction into the academic sphere of José Gerson da Cunha's Sabayadbri Khanda (Cunha, 1877), a text that provided a brahmanical genealogy to this group and allowed the caste activists to claim that the various jati were in fact sub-castes that had broken away for reasons of historical accident from a single caste once located solely in Goa. More significant was the publication in the Bombay Gazetteer of Cunha's text The Konkani Language and Literature (1881), which twines Aryan and brahmin roots to Konkani and ties Konkani to the GSB caste. For reasons of being the official space for colonially approved ethnographic knowledge, publication of this text in the Gazetteer allowed persons such as Valaulikar space for their own activism with regard to the Konkani language and creating the space for their caste group within the public sphere.

This identification of Konkani as a group marker of the GSB was not without its own problems. An insight into these complications is provided in the following extract from Valaulikar's text, The Triumph of Konkani where he responds to the position of Raghunath Talwadkar, a member of the GSB caste opposed to the adoption of Konkani as the GSB mother-tongue:

After taunting Pundalikbab, the next target of Raghunathbab's verbal cannonade is the illustrious son of Goa, Dr. Jose Gerson da Cunha of hallowed memory. Raghunathbab calls him by such expletives as "defiled Christian", "bigot" and "goanese"; 8 and his excellent essay "The Konkani Language and Literature" is rubbished as a pamphlet; and his was an essay which was commissioned by the British Government and was acclaimed by scholars. From this we can gauge the enormity of Raghunathbab's sagacity. I doubt whether, in his entire lifetime, Raghunathabab will ever be able to just read and digest the research done and books written by Dr. Gersonbab on coins and ancient history. How can one reconcile Raghunathbab's ridicule with the acclaim earned by Dr. Gersonbab in Asia, Europe and America?

\footnotetext{
${ }^{8}$ In the context of this term, Parag Parobo points out that "around the 1940s, guided by the nationalist imaginations of nation and culture, the Hindu elites of Bombay refashioned the term Goanese to mean 'half/local European', a taunt for the Catholic Goans” (2015: 41).
} 
Dr. Gersonbab is certainly not a religious fanatic; he is a large-hearted, virtuous scholarly Brahmin who, having been born in Goa, endeavoured to spread worldwide the glory of his motherland. ${ }^{9}$ And when Raghunathbab realises this, I am sure, he will be filled with great remorse. (Valavalikar, 2003: 32)

This extract is critical for the wealth of information it provides about social conflicts at the time. Marathi was the preferred language of the elite, mobile and urbanised families from these jati who were already established in Bombay, who saw themselves alone as Saraswat and were jostling for power with other Marathi-speaking brahmin groups. Konkani, on the other hand, was not only seen as the language of the newly arrived lower status migrants from the villages of the Bombay Presidency and Goa, but also the name for the jat $i$ they came from, especially in the Kanara districts of the Bombay Presidency. Furthermore, it also demonstrates the manner in which Konkani was associated with "defiled" Christians.

With this information, it becomes obvious that the history of Konkani and the GSB is also a history of conflict between $j a t i$ and the differing imaginations of themselves within the emerging caste group. Indeed, despite Valaulikar's efforts, Marathi would continue to be seen as the language of elites within these jati, causing considerable conflict within the caste at the time of the language agitation in Goa. Take, for example, the fact that Laxmikant Bhembre, the father of the contemporary Nagari stalwart, Uday Bhembre was a staunch supporter of Marathi as an official language for the state of Goa. ${ }^{10}$

It is in this larger context of the need felt for unification and the opposition to this project that the work of Valaulikar should be seen. A quick review of his biography will bear out this fact.

\footnotetext{
9 If Gerson da Cunha's works were critical to the buttressing of claims to a brahmanical status for the GSB, in this extract Valualikar returns the favour by including the former within the fold of brahminhood. However, it is not merely Cunha who is recognised as brahmin; Valaulikar also recognises "Senhor Jose Antonio Ismael Gracias" as "a learned Christian brahmin from Loutolim" (Valauvalikar, 2003: 81) and goes further to recognise the village of Loutolim as one "famous for learned Brahmins", going on in the subsequent sentence to point out that " $[t]$ he illustrious historian of the last [19 $\left.9^{\text {th }}\right]$ century, Felipe Neri Xavier was a Christian brahmin, native of this village" (ibidem: 82). In so doing, Valaulikar was probably discursively attempting a number of objectives. The first was to build on Gerson da Cunha's own project of identifying himself as a brahmin (Vicente, 2012: 19, 27-29, 179), recognising the brahminness of Catholic brahmins, wresting them in some way from brahmanical notions of impurity, as well as creating a civil society that would include both Hindus and Catholics - so long as they were all brahmin.

${ }^{10}$ An anecdote related to the difference of opinion within the same household may prove interesting. When Uday Bhembre was asked how he, a son of Laxmikant Bhembre, could argue that Konkani was his mother tongue, when his father Laxmikant Bhembre argued for Marathi as his own mother tongue, Uday Bhembre is reported to have responded: "But don't you know that my mother, and my father's mother are not the same?"
} 


\section{Valaulikar as Caste Activist}

Conlon (1974) indicates that the Samyukta Gauda Sarasvata Brabmana [GSB] Parisad ("United Gauda Saraswat Brahmin Conference") was founded in 1910, and its energies eventually waned by the year 1917. It revived itself for a conference in 1935, but was largely dormant in the rest of the period. However, prior to 1910, and even subsequently, the environment in Bombay proper, the larger Bombay Presidency and the territory of Goa was charged with the excitement of this attempt at creating a single caste as well as the challenges presented vis-à-vis these efforts, both by those within the groups that the caste was trying to assemble as well as those castes that were opposed to these related jati.

Exploring the significance of Shenoi Goembab, the pen-name which the young Valaulikar adopted, provides an insight into the context within which his work emerged.

Kiran Budkuley points out that one of the reasons for Valaulikar's use of Shenoi as his pen-name was to "herald to the world proudly the glory contained in the word 'shenoi' which was often misconstrued or misinterpreted by petty individuals for short sighted motives" (Budkuley, 2003: 17, italics added; see also Wagle, 1970a and 1970b). What is being referenced here is Valaulikar's investment in the battle to gain respect for his caste in the face of the dismissal by other brahmin castes in the city of Bombay. A less hagiographic description of the text in which Valaulikar restores the honour of the term Shenoi points out that "the essay titled 'Shennai', which forms the main part of his collection of essays in Marathi, deals with the different brahmin sub-castes in Maharashtra and Konkan, in order to prove the superiority of the GSBs among all” (Desai, 2002: 94, fn. 21). In the course of proving his caste's superiority, Valaulikar is reported to have played on the Dravida-Gaud distinction. The Saraswats, he argued, were Gaud, and hence Aryan, whereas the Chitpawan and Karhada, were Dravida, that is, Dravidian brahmins and hence not quite on par with the Aryan GSB. Consequently, it becomes obvious that Valaulikar's adoption of the term Shenoi as a nom de plume and his fight for its respect was not disconnected from the affirmation of caste superiority.

Similarly, the second part of his name was connected with a slight he suffered when he migrated from Goa to Bombay. Goembab seems to have been the manner in which the established Saraswat families in Bombay referred to the city's lower-class brahmin migrants from Goa (Naik, 2007: 8 -9). Once again, establishing coeval status with the Saraswats in Bombay appears to have been central to his life's project.

One of the many works he penned under this name was the poem Goenkaaracho Mumbaikaar in 1910. In the tract Shenoi Goembab: The Man 
Who Resurrected Konkani, Budkuley wrote: "It lampoons the presence, the hypocrisy and the ultimate misery of a man who pawns his self-respect and identity for petty pelf and false sense of borrowed grandeur, only to be disillusioned and chastened at the end" (Budkuley, 2010). The poem is clearly mocking the Marathi-speaking Saraswats of Bombay who refused to accept a Konkani identity. What is noteworthy is that in this process Valaulikar, his biographers and commentators managed to normalise the idea of a single GSB caste unmarked by internal hierarchies or distinctions. Secondly, in keeping with the racist and nationalist frameworks of nineteenth-century epistemologies, they constructed Goa as the original homeland of this Konkani caste. Finally, it asserted Konkani alone as the language of the GSB caste (and, by extension, of all Goans), and the use of Marathi the result of misplaced sensibilities. Narayan Desai points out that Valaulikar simultaneously constructed Marathi as the language of the Chitpawans and Karhadas, the two major brahmin jati in Maharashtra, whom the Saraswats were pitted against (2002: 93-94). These early assertions of monolingualism and linguistic identity would nevertheless require more time and the energies of multiple actors before these suggestions could be matter-of-factly asserted, as is today the case.

The episode involving Valaulikar and his school teacher in Bombay who "slighted a particular community in class, making irresponsible and disparaging comments about the people concerned" (Budkuley 2003: 24-25, italics added) also demonstrates how Valaulikar was part of a larger caste-battle aimed at securing a space for his caste-group in late colonial modernity. What is relevant to the recounting of this incident is that subsequent to these comments, the young Valaulikar penned an essay, managed to get it published, and posted a copy of the publication to the teacher. Erasing all references to the castes involved, or the context of this comments and Valaulikar's response, allows his biographers to use this episode to demonstrate his strength of character and dedication to the cause of truth. While these character traits may have been present, what is critical to this discussion is that it also indicates that the young Valaulikar was sufficiently aware of and invested in the caste battles that animated the literate segments of the denizens of Bombay.

That Valaulikar's work was motivated by the caste battles being fought simultaneously both "within" the emerging Saraswat caste and against other brahmin castes is made obvious by a close reading of the texts he produced. A review of the work of his biographers and commentators does not provide any clue as to the audience he was largely addressing. Indeed, if one relies on these works then one is led to believe that the audience he was addressing was a secular civil society. This audience was indeed "secular" in that given the manner in which it drew on popular preoccupations with Aryan heritage 
and brahmanical roots and a space for the Goan in diverse public spaces, both in Portuguese and British India, it eventually grew to incorporate Catholics from the "upper castes" and hence transcended a merely religious community. It meets the requirements of civil society in that this rhetoric was addressed to a larger audience in the public sphere. But this does not reveal the dominant constituents of this civil society.

If one reads Valaulikar's works closely, scanning his logics for clues as to which groups they would appeal to, one realises that the civil society that he was addressing was essentially a Hindu and especially a brahmin audience, in particular the members of the GSB caste whose unification cause he was furthering (Valaulikar, 1985, 2008). The point that this discussion continues to attempt to is that it is indeed this largely occluded caste context of Valaulikar's work that sets the stage for the conflicts which would come to mark the political history of the Konkani language and the delineation of post-colonial Goa's civil society.

A significant number of Valaulikar's writings translated into English were delivered within the context of a specific associational setting, the Goa Hindu Association (GHA), established as a cultural association for the Goan "Hindus" of Bombay akin to those available to the Goan Catholics. Valaulikar was involved with the establishment of the GHA in 1919, and was subsequently elected Joint Treasurer in the first Executive Committee of the association until about 1937 (Budkuley, 2003). ${ }^{11}$ Budkuley also reports that the most substantial of his works, Goenkaranchi Goianbhaili Vosnook ("The Travels of Goans outside of Goa") was originally a lecture delivered to a "public" audience hosted by the GHA and the Saraswat Brabman Samaj on $22^{\text {nd }}$ May, 1927. The aim of this lecture series was to boost GSB pride and to create a history for this group fighting for place in the public spaces of the Bombay Presidency. ${ }^{12}$

\footnotetext{
${ }^{11}$ See also the website of the Goa Hindu Association, which provides details regarding the founders of the Association and brief information about its origins: http://goahinduasso.org/founders. Accessed on 14.03.2018.

${ }_{12}$ Despite being based in Bombay, the GHA traversed the worlds of Portuguese and British India. This is made obvious in a certificate of honour issued by the Association in 1920 to Shivram Balwant Deshpande for being the first Goan Hindu (i.e. brahmin) to travel to Portugal for higher studies despite the threats by the pontiff of the caste and supported by traditionalists who threatened to excommunicate him (Kamat, 1996: Appendices). The familiarity of these brahmins with Portuguese culture is more than evident by the fact that the certificate, which is in Marathi, includes a quotation in Portuguese from Canto IV - stanza 78 of Camões' Os Lusíadas. More recently, the GHA was also used as a platform to publish the book Goa: Concepts and Misconcepts (Angley, 1994), which presents a Hindu brahmin perspective of the territory, emphasising its Indian-ness rather than the trope of Goa Portuguesa, used first by the Estado Novo and continued by the Indian state (see Trichur, 2013: 17-30).
} 
Currently in Goa there is an on-going debate of whether one should take up a job or not, you should not jump into this debate and get washed away. You can call a job by whatever name, you can insult the job and say that it is not worth doing but even then it does not change the job or its content. If we Hindu Goans kick aside government jobs, then our Christian brothers will hold them in high esteem; even if they kick these jobs aside, we will have the Parsis from Mumbai or the Iyer-Iyengars from Madras come and take up these jobs and enjoy success. We will then not have the opportunity to get these jobs. (Valaulikar, 2008: 29)

Like other reformists, Valaulikar extols the brahmin community when they shed traditional prejudices and taboos to participate in the opportunities being opened by colonial modernity (Valaulikar, 2008: 30$).{ }^{13}$ More specifically, it encouraged the younger generation of the GSB to follow what Valaulikar represents as their noble learned ancestors and challenged the idea that the GSB was backward in education (ibidem: 13-16; 23-33). The setting of modernity that Valaulikar established then involved the rejection of traditional interdictions of a provincial community, urging them to take up skills such as singing or arts formerly associated with lower castes, encouraging them to enter "modern" professions, especially those within Government service, and stressing the caste's Aryan heritage.

\section{Working Towards a Konkani Homeland as a Sphere of Caste Autonomy}

From the discussion above it appears that one of the primary motivations underlying Valaulikar's work was the promotion of the cause of GSB unification. During the course of his efforts, and building upon the labours of other caste activists, he identified Konkani as a significant factor. As was the case with other upper-caste activists in colonial British India, this caste mobilisation was not uninformed by nationalist ambitions. ${ }^{14}$ Still, he is reported to have refused to directly address this nationalist cause and was more focussed on the issue of language as a caste issue. His argument in response to the question as to why he did not engage in the nationalist struggle was, appropriately enough, that "even in linguistic issues there is a lot of politics" (Budkuley, 2003: 84, italics added).

\footnotetext{
${ }_{13}$ For a review of the manner in which the GSB began to educate themselves, first in Kannada and subsequently in English, both as a way to rise in the administrative hierarchy as well as to modernise themselves, see Conlon (1977), especially Chapter 5, "A District Divided: Modernization in the Mofussil, 1860-1890”, pp. 86-113. Education, especially in English, offered individual substantial opportunities to rise in the official hierarchies and assert power in the larger socio-political sphere. ${ }_{14}$ This is not surprising given that the Goa Congress Committee was established in 1928, the same year that it was affiliated with the Indian National Congress, with affiliation in the All India Congress Committee (Kamat, 1996: 217).
} 
He [Raghunath Talwadkar] says that Goa cannot be an independent state but I doubt this will find favour with many Goans. The day the Indian region extending from the Himalayas to Kanyakumari and from Karachi to Burma will become independent, our Goa will automatically become free; and it will freely participate in the country's gigantic task as an integral organ of India. Let Raghunathbab and others of his ilk bear this firmly in mind. In order to be free, Goa certainly need not make the mistake of becoming a part of Marathan. Goa is not a part of Marathan, never was, will never be and never must be. (Valavalikar, 2003: 5; all bold emphasis in the original)

The imagination of a European-free India comprising various linguistic homelands was an ideal already in circulation in the early 1900s. It needs to be noted that by about 1917 the Indian National Congress, established in 1885, had to amend its organisational structure to accept the principle of linguistic division as a fundamental organisational feature under pressure from linguistic nationalist groups, a trend that first commenced with the establishment of the Andhra Mahasabha in 1910 (Mitchell, 2010: 38) and the subsequent formation of Pradesh Committees based on language groups (Nair, 2011: 54).

In this situation, where it seemed clear that the future of an independent India would involve the creation of civil societies marked by the dominance of one language within the space of that particular civil society, and that this language would be determined by brahmanical groups whose dialect was understood to be the exemplification of the most ideal version of the language, it is no surprise that Valaulikar, in the context of the caste battles in colonial Bombay, chose to stress Goa as the space of Konkani and consequently of the GSB caste, who were deemed to be the exemplars of this language:

My words would, of course, be those of a Brahmin, an intelligent and cultured person, but they must also be those of a labourer i.e. they should be intelligible to a rustic and ignorant person. Even children should not find them difficult to comprehend. (Naik, 2007: 19)

This reference to the language of the labourer (lower caste person) should not persuade us that Valaulikar contemplated a Konkani drawn from all segments of the Goan polity. The extract above makes it rather evident that the terminology used should be "intelligible to a rustic and ignorant person" just as it would be intelligible to a child, continuing the long tradition of viewing lower caste persons as less intelligent or infantile. Other segments of the Konkani Bhashechem Zoit also clearly demonstrate that he saw Konkani as a language of the GSB, being an Aryan language, although if 
pressured, he was willing to concede that "it would not be far wrong to say that it has been formed by the amalgamation of the language of the original inhabitants of the place and the Aryan language of the Saraswats" (Valavalikar, 2003: 86-87). However, he also makes it quite clear that if one considers "any language in the world, $[\ldots]$ you will find that the educated class exerts the maximum influence upon it. Hence, it should not come as a surprise that Konkani has been influenced by Saraswat Brahmins" (ibidem: 86).

The concessions that Valaulikar made only extended to those contesting his critics' arguments that suggested the non-Aryan nature of Konkani but also went on to affirm that "Konkani is not the language of the Saraswats alone but on all the four varnas. Today, people of all castes speak this language." (ibidem, bold emphasis in the original). In other words, in the final accounting, it was the GSB who best embodied the language, as evidenced in his rather dismissive words about the relationship between Dravidian brahmins in Goa and their relationship with the Konkani language.

they do not consider Konkani as their mother tongue. Although they came and settled in Goa a considerably long time ago, they cannot yet speak pure Konkani. If at all they try to speak it, then their non-brahmin accent is clearly discernible. Therefore it is pointless to expect Konkani language from Dravidians. (ibidem: 78) ${ }^{15}$

Given the nature of the debate surrounding the marking out the differences of the Konkani speaker, it was not long before the idea of a separate homeland should also have emerged. Though Valaulikar may not have been the first person to articulate it, given his centrality in the imagination of Konkani language activists, he is regarded as having first conceived of this idea. Subsequently, José Pereira points out that the idea of a Konkan state, as a Sagari Pranta or "Maritime Province", was articulated by a prominent lawyer from Karwar, Madhav Manjunath Shanbhag, who worked along with Valaulikar to establish the Konkani Parishad (Konkani Conference). This concept was later elaborated by another GSB "Kakasaheb Kalelkar ${ }^{16}$ [...], but was first presented in cogent intellectual terms by George Mark

\footnotetext{
${ }^{15}$ Given that the non-brahmin populations were/are considered to be non-Aryan, i.e. Dravidian, this dismissive treatment of the Dravida brahmins in Goa could well be, and is in fact, extended to non-brahmins who speak Konkani, laying the basis for the argument that the best Konkani is that spoken by GSB.

${ }^{16}$ For a biography of Kalelkar, himself a Saraswat, which touches on points relevant to the history of GSB mobilisation, see Prasad (1965: 20). On the manner in which Kalelkar involved himself with politics in Goa, and the extent to which his caste identity was critical to his support for Konkani, see Kanekar (2011: 159).
} 
Moraes [...], whose arguments were reinforced by the fervent rhetoric of Bhaskar Anand Saletore [...]" (Pereira, 1992: 20-21).

In her discussion of the developments of the demand for a Karnataka state from the 1940s, Janaki Nair points to the fact that caste was recognised as playing a significant role. As evidenced by their surnames, both Madhav Shanbhag and Bhaskar Anand Saletore were from the North Kanara region of the former Bombay Presidency. If the GSB faced challenges in Bombay city, the capital of the Presidency, things were no less tense in the districts and its environs. In his discussion of the politics of script in Goa, Desai highlights that the Konkani-speaking brahmin caste groups in Kanara had to deal with "the hostility of the regional Brahmin groups such as Shivallis", who were a Kannada-speaking brahmin caste, and used Konkani as a way to consolidate their forces scattered across different states (Desai, 2002: 245). As should be obvious from this discussion, the Konkani Parishad did not emerge from a tabula rasa but rather a field that was fraught with challenges, including inter-caste rivalries and a struggle for local dominance. ${ }^{17}$

At its first meeting in Karwar in 1939, this convention focussed on a fivefold programme, which included "Striving to create a uniform standardized language, and; Adopting the original and natural Devanagari script for Konkani" (Budkuley, 2003: 69). Desai points out that this decision roughly coincides with the period of insistence on Hindi and Nagari as a part of the Indian nationalist struggle (Desai, 2002: 88; see also Rai, 2001). Indian modernity was being cast at the national level in Sanskritic terms, and this trend was being followed by sub-national movements as well. The Konkani language establishment in Goa today refer to this resolution of the first convention when suggesting that the decision regarding the script for Konkani was fixed by consensus. It is easy to present this decision as a consensus since the convention was marked by the presence of Catholic activists and other efforts undertaken by this group. ${ }^{18}$ However, after the preceding discussions, the unspoken caste interests and locations of these Catholic representatives should be obvious, allowing us to recognise how the consensus which came about was indeed one of a definite caste group

\footnotetext{
${ }_{17}$ To an extent, the Konkani Parishad seems to have also walked in the footsteps of the GSB unification movement as well. Just like the Parishad, the Gaud Saraswat Brahman Parishad first organized in Mangalore in 1907 for a restricted audience of Vaishnavas from the Mangalore region alone, soon came to shift in venue and attract GSB from different parts of southern and western India. While the second meeting was held in 1908 in Mangalore, the third meeting was held in 1909 in the city of Belgaum (Kamat, 1996: 122-123).

${ }_{18}$ While the unanimity of the consensus in Karwar is often harped upon, the fact that a similar resolution to the effect was opposed in the second Parishad at Udipi in 1940 is almost never mentioned (Desai, 2002: 286-287).
} 
and its attempts to secure a space in the modern order that was beginning to emerge in the nineteenth century.

It was much more than mere caste affinities that produced this conversation between the two elite groups. The ability to see the Hindu GSB as a 'fraternal other' was aided by the choices made by the Catholic native elite in Goa in the early nineteenth century as a way to adopt the epistemological frames dominant in British India. What needs to be pointed out, however, is that these choices were not made by local native elites alone. Rather, metropolitan elites, such as Rivara, working to make themselves and the polity they represented modern, also played a critical role. These frames now came to dictate their view of the world, enabling them to view the GSB as fraternal and themselves as the orphaned prodigal child of this family due to their depicting themselves as the ones torn from the harmonious pre-colonial 'state of nature' by virtue of their conversion to Christianity. The colonial-era sentiment only grew stronger in post-colonial times, deepening this elite's desire to correct historical accidents and return to the "mainstream" ${ }^{19}$ In later times - especially following Goa's integration into the Indian Union and with the eventual recognition of only one form of the Konkani language, i.e. the Nagari script Antruzi as opposed to the Roman scripted versions - this sentiment would facilitate the successors of this Catholic elite to be satisfied with playing second fiddle to the agendas articulated by the GSB and brahmanised Hindu interests.

\section{Conclusion}

The aim of this article has been to offer a reading of Valaulikar which, in including the context of the caste battles he was involved in, sheds greater light on the man's project. It demonstrates that if today Konkani is seen as the language that marks Goan identity - itself a prime feature of Valaulikar's project - it is because this project found support in the mobilisation among dominant Hindu jati, not just in Goa but along the subcontinent's western seaboard. Adding to this is the fact that Valaulikar's interest in Konkani was not in defence of the language in and of itself, but more for what the linking of this language with the GSB group could secure for the community in whose life he was deeply involved.

\footnotetext{
${ }^{19}$ In this context, reference must be made to a Letter to the editor of the Navbind Times written by B. H. Pai Angle on 9 October 1985. Written in the course of the Konkani language agitation, Angle, who was a proponent of Marathi as the language of Goa argues: "If the Portuguese had not stepped into Goa we would have been all Hindus and the culture and traditions would have the same [sic] as those of Hindus. But unfortunately part of the population was converted and along with the religion the Western culture [sic] was thrust on them. Otherwise we are all brothers and sisters of the same soil and we remained with that relationship till the Liberation."
} 
That Valaulikar was essentially a caste activist should not detract from those who hail him as a secular icon. To the extent that he worked with Catholics and recognised Catholic interventions, the man was by the dominant understanding definitely secular. And yet, just as with the linguistically marked public sphere that he helped engineer, his secularism was also caste-marked. Given that his project was to link Konkani with the GSB and emphasise it as a brahmin language, he worked to craft a larger sphere, one that would include not just Hindus, but also Catholics, but all the while recognising the brahmin-ness of the Catholics he quoted approvingly. He was, in turn, able to recognise this brahmin-nesss precisely because these Catholic elites caught in the frames of nineteenth-century epistemologies sought to have their brahmin-ness recognised as a part of their identity.

The final observation to be made is that these exertions initiated by Valaulikar are in great part responsible for the nature of the contemporary public sphere in Goa. Located within these two exertions also lie the reasons for the manner in which non-dominant caste Catholics in Goa have been relegated to the place of second-class citizens, where even though the official language of the state is Konkani, the Konkani they speak is dismissed as unacceptable for having been marked by Portuguese and Catholic interventions. Thus it is that the terrain of twenty-first century Goa is marked by the long shadow of the nineteenth.

\section{Edited by Scott M. Culp}

\section{References}

Angley, Prabhakar S. (1994), Goa: Concepts and Misconcepts. Bombay: Goa Hindu Association.

Bayly, Susan (2001), Caste, Society and Politics in India from the Eighteenth Century to the Modern Age. The New Cambridge History of India, vol. 3. Cambridge: Cambridge University Press.

Botelho, Afonso Manuel (2011), Language and Early Schooling in Goa. Panjim, Goa: Directorate of Official Language, Government of Goa.

Brass, Paul (2005), "Indian Secularism in Practice", Indian Journal of Secularism, 9(1), 115-132.

Budkuley, Kiran (2003), Shenoi Goembab: The Man and His Work. Margao, Goa: Asmitai Pratishthan.

Budkuley, Kiran (2010), "Shenoi Goembab: The Man Who Resurrected Konkani”, Goan Causes. Accessed on 16.10.2010, at http://www.goancauses.com/shenoi.htm. 
Conlon, Frank F. (1974), "Caste by Association: The Gauda Sarasvata Brahmana Unification Movement”, The Journal of Asian Studies, 33(3), 351-365.

Conlon, Frank F. (1977), A Caste in a Changing World: The Chitrapur Saraswat Brahmans, 1700-1935. Berkley/Los Angeles, California: University of California Press.

Cunha, José Gerson da (ed.) (1877), The Sabyadri Khanda of the Skanda Purana: A Mythological, Historical, and Geographical Account of Western India. Bombay: Thaker, Vining and Company.

Cunha, José Gerson da (1881), The Konkani Language and Literature. Bombay: The Bombay Gazeteer.

Desai, Narayan B. (2002), "Politics of Script: The Case of Konkani (1961-1992)". Doctoral Thesis in Political Science, Goa University, Taleigão, India.

Dhareshwar, Vivek (1993), "Caste and the Secular Self", Journal of Arts and Ideas, 25-26, December, 115-126.

Fernandes, Jason Keith (2013), “Citizenship Experiences of the Goan Catholics”. Doctoral Thesis, ISCTE - Instituto Universitário de Lisboa, Lisboa, Portugal. Accessed on 16.04.2018, at http://hdl.handle.net/10071/6582.

Kamat, Varsha Vijayendra (1996), "Socio-Political and Religious Life in Goa (1900 to 1946)". Doctoral Thesis, Goa University, Taleigão, Goa, India. Accessed on 01.02.2018, at http://hdl.handle.net/10603/32126.

Kanekar, Suresh (2011), Goa's Liberation and Thereafter: Chronicles of a Fragmented Life. Saligão, India: Goa 1556.

Keiko, Yamada (2010), "Origin and Historical Evolution of the Identity of Modern Telugus”, Economic and Political Weekly, xLv(34), 57-63.

Mitchell, Lisa (2010), Language, Emotion, Politics in South India : The Making of a Mother Tongue. Ranikhet, India: Permanent Black.

Naik, R. N. (2007), Shenoi Goembab. Makers of Indian Literature Series. New Delhi: Sahitya Akademi. Translated by Sebastian M. Borges [1 ${ }^{\text {st }} \mathrm{ed}$.].

Nair, Janaki (2011), “The 'Composite' State and Its 'Nation': Karnataka's Reunification Revisited”, Economic and Political Weekly, XLVI(47), 52-62.

Narayan, Badri (2004), "Inventing Caste History: Dalit Mobilisation and Nationalist Past”, in Dipankar Gupta (ed.), Caste in Question: Identity or Hierarchy? Contributions to Indian Sociology: Occasional Studies, 12. New Delhi: Sage, 193-220.

Naregal, Veena (2001), Language, Politics, Elites and the Public Sphere: Western India Under Colonialism. Opus 1 Series. Delhi: Permanent Black.

O'Hanlon, Rosalind; Minkowski, Christopher (2008), “What Makes People Who They Are? Pandit Networks and the Problem of Livelihoods in Early Modern Western India", Indian Economic Social History Review, 45, 381-416.

Parobo, Parag D. (2015), India's First Democratic Revolution: Dayanand Bandodkar and the Rise of Babujan in Goa. New Perspectives in South Asian History series, vol. 2. New Delhi: Orient Blackswan Private Limited. 
Patil, Urmila Rajshekhar (2010), "Conflict, Identity and Narratives: The Brahman Communities of Western Indian from the Seventeenth through Nineteenth Centuries". Doctoral Thesis, University of Texas at Austin, Austin, United States of America. Accessed on 01.02.2017, at https://repositories.lib.utexas. edu/bitstream/handle/2152/ETD-UT-2010-12-2082/PATIL-DISSERTATION. pdf? sequence $=1$.

Pearson, Michael Naylor (1972), "Indigenous Domination in a Colonial Economy: The Goa Rendas, 1600-70", Mare Luso-indicum: Etudes et documents sur l'bistoire de l'Océan Indien et des pays riverains à l'époque de la domination portugaise, II, 61-73.

Pereira, José (1992), Literary Konkani: A Brief History. Panjim, Goa: Goa Konkani Akademi [2 $2^{\text {nd }}$ ed. $]$.

Pinto, Rochelle (2007), Between Empires: Print and Politics in Goa. New Delhi: Oxford University Press.

Prasad, Madho (1965), A Gandbian Patriarch: A Political and Spiritual Biography of Kaka Kalelkar. Bombay: Popular Prakashan.

Rai, Alok (2001), Hindi Nationalism. Tracts for the Times series, 13. New Delhi: Orient Longman Private Limited.

Ramaswamy, Sumathi (1997), Passions of the Tongue: Language Devotion in Tamil India, 1891-1970. Studies on the History of Society and Culture series, 29. Berkley/Los Angeles, California: University of California Press.

Trichur, Raghuraman S. (2013), Refiguring Goa: From Trading Post to Tourism Destination. Saligão, India: Goa 1556.

Valaulikar, Vaman Raghunath Varde (1985), "The Triumph of Konkani”, The Herald, August 4. Translated by R. N. Naik.

Valaulikar, Vaman Raghunath Varde (2008), For the Konkani Students (Konkani Vidbyarthyank). Panjim, Goa: Goa Konkani Akademi. Translated by Srinivas Kamat [1 $1^{\text {st }}$ ed. $]$.

Valavalikar, Shenoi V. R. Varde (2003), The Triumph of Konkani: A Translation of Shenoy Goembab's Konkani Bhashechem Zoit. Translated by Sebastian M. Borges. Margao, Goa: Asmitai Pratishthan [orig. ed.: 1930].

Vicente, Filipa Lowndes (2012), Other Orientalisms: India between Florence and Bombay 1860-1900. New Delhi: Orient Blackswan Private Limited. Translated by Stewart Lloyd-Jones.

Wagle, N. K. (1970a) "The History and Social Organization of the Gauda Saraswata Brahmanas of the West Coast of India”, Journal of Indian History, 48(1), 8-25.

Wagle, N. K. (1970b), "The History and Social Organisation of the Gauda Sarasvata Brahmanas of the West Coast of India”, Journal of Indian History, 48(2), 295-333. 
Received on 15.12.2017

Accepted for publication on 23.03.2018

\section{Jason Keith Fernandes}

CRIA - Centro em Rede de Investigação em Antropologia, Instituto Universitário de Lisboa

Av. Forças Armadas, Edifício ISCTE-IUL, 1649-026 Lisboa, Portugal

Contact: jason.k.fernandes@gmail.com

\section{Transpondo os séculos: uma breve biografia de Wamanrao Varde Valaulikar}

As representações existentes do final do século XIX da personalidade de Wamanrao Varde Valaulikar (1877-1946), conhecido pelos ativistas konkani como Shenoi Goembab, são marcadas por um caráter hagiográfico. O presente artigo oferece uma biografia do homem que evita essas hagiografias nacionalistas para o colocar no contexto da sua época e demonstrar o seu papel primordial como ativista na criação da casta brâmane Gaud Saraswat. Ao fazê-lo, o artigo mostra como as bases para a esfera pública goesa contemporânea foram estabelecidas no século XIX.

Palavras-chave: ativismo; Goa; língua concani; Shenoi Goembab; Wamanrao Varde Valaulikar (1877-1946).

\section{En transposant les siècles: une brève biographie de Wamanrao Varde Valaulikar}

Les représentations existantes de la fin du $\mathrm{XIX}^{\mathrm{e}}$ siècle de la personnalité de Wamanrao Varde Valaulikar (1877-1946), connu comme Shenoi Goembab par les activistes konkani, sont marquées par un caractère hagiographique. Le présent article en offre une biographie qui évite ces hagiographies nationalistes en le situant dans le contexte de son époque et en apportant la preuve de son rôle primordial comme activiste dans la création de la caste brahmane Gaud Saraswat. Ce faisant, l'article démontre comment les bases de la sphère publique de la Goa contemporaine furent établies au XIX ${ }^{\mathrm{e}}$ siècle.

Mots-clés: activisme; Goa; langue konkani; Shenoi Goembab; Wamanrao Varde Valaulikar (1877-1946). 